\title{
Economic Aspects of Food Security in Ukrainian Meat and Milk Clusters
}

\author{
Natalia Vasylieva \\ Department of Informative Systems and Technologies, Dnipro State Agrarian and Economic University, \\ Ukraine
}

\begin{abstract}
The goal of the article was to accomplish mathematical estimations of the misbalances and calculate available reserves in providing food security by meat and milk. This issue has considerable economic and social values that imply maintaining agrarians' welfare and people's health. The disproportions in meat and milk clusters have been analyzed by means of Lorenz curves and inequality indicators - Hoover and Theil indices, Gini coefficient, and also 20:20 Ratio. It has been grounded that increasing animal productivity and wholesale prices for meat and milk, as well as reducing their retail prices and raising solvency of population would be the essential reserves in supporting food security in the agricultural clusters. The proposed model of defining interregional clusters has made possible to identify the priority options of providing food security and balancing meat and milk supply and demand. All the offered developments and recommendations have been verified at Ukrainian meat and milk clusters.
\end{abstract}

\section{Keywords}

Food security; meat and milk clusters; indicators of misbalances; production and consumption; productivity and profitability; prices and solvency; cluster model.

Vasylieva, V. (2017) "Economic Aspects of Food Security in Ukrainian Meat and Milk Clusters ", AGRIS on-line Papers in Economics and Informatics, Vol. 9, No. 3, pp. 81 - 92. ISSN 1804-1930. DOI 10.7160/aol.2017.090308.

\section{Introduction}

Food security is one of the key economic issues for agrarians and scientists all over the world. The problem of balancing agricultural clusters is also a very important objective, relying on the primary vital human right on healthy nutrition. Furthermore, providing rational agriculture is a social and ecological responsibility as for preserving and passing undamaged natural recourses and clear environment to the future generations. It was determined that an accelerated growth of population brought new challenges to conventional agriculture (Grafton et al., 2015). The appeared advantages are connected with the increasing demand for food products, while the additional obligations force to satisfy the contemporary norms of products quality.

At present agrarian markets in Europe are saturated with sufficient quantities of qualitative food products, according to the modern nutrition standards. Therefore, the main task of European agriculture is to continue its balanced economic development in conditions of strong competition and limitations to production volumes.

While integrating into European economic space and following the best world examples, Ukraine should modernize its agrarian sector and, simultaneously, eliminate the striking disproportion between branches of crop and animal production. Practical actuality of these issues is focused on two points. On the one hand, Ukrainian animal husbandry does not realize own resource potential, especially in cattle and pigs breeding. It results in a crucial breaking of nutrition maintenance of Ukrainian population by meat and dairy products. On the other hand, a poor solvency in Ukraine affects demands for meat and milk, which are even less than the suggested supplies of the national producers. Thus it is necessary to study correlation between consumption and production of beef, pork and milk at Ukrainian agricultural markets.

Analysis of recent relevant publications highlights scientific actuality of explorations on providing 
food security in the global scale. Namely, Godfray and Garnett (2014) presented a new concept of uniting food security and sustainable intensification under the principle "more food with less environmental impact", which emphasizes ecological components of saving biodiversity, multifunctional landscapes, and animal welfare together with facilitating rational human nutrition. Contemporary criteria and indicators of measuring food security were obtained by Headey and Ecker (2013), as well as Kavallari et al. (2014). Grafton et al. (2015) targeted their strategic researches on ensuring food security by countries and agricultural branches. The last ones correspond to the Cluster Concept, developed by Porter (2000), on achieving essential competitive benefits in increasing productivity, expanding market scopes and accelerating innovative modernization by territories and products. Hansen (2013) clarified the effectiveness of this approach in the largest agricultural and food European clusters. At the same time Phillips et al. (2012) proved it for the similar prosperous clusters of North America.

The grounded solutions of the formulated problem need applications of mathematical methods that would be a robust basis for the obtained conclusions and recommendations. For a long time researches on applying mathematical apparatus to the problems of agricultural economics attract scientists' attention in diversified directions all over the world. Namely, these issues found their fundamental reflection in the developed and generalized results of Thornley and France (2007), Bessler et al. (2010), as well as Mitchell (2011).

As a matter of fact, mathematical models and assessments should be "the more - the better" adjusted to the features and factors of the expected applied economic environment. Therefore, this study is focused on analyzing Ukrainian clusters of meat and dairy products. It continues the previous ones of Vasylieva $(2015 ; 2016)$ on simulating optimal animal numbers and productivities for saturating Ukrainian domestic regional markets with meat and milk, decreasing their costs, providing profitable livestock breeding at the level of agricultural enterprises and modelling clusters of intensified development in the national households. At the same time, the problem of facilitating food security by animal products is still an open question in terms of demand and supply or production and consumption in the whole country. It is not only significant economic, but also urgent social issue, since balanced production of meat and milk means welfare and employment of rural population, while sufficient consumption of meat and milk supports health of people at present and for the future. Thus, the goal of this investigation was to assess the current misbalances and to define some reserves on maintaining rational nutrition by meat and milk with regard to providing Ukrainian food security. This goal implies solving the following tasks:

- to choose complex of indicators for evaluating disproportions in Ukrainian meat and milk food security;

- to ground quantitative options in increasing meat and milk production;

- to figure out reserves of growth in meat and milk consumption;

- $\quad$ to create a mathematical model of regional clusters, which facilitate balanced food security in Ukrainian animal husbandry.

\section{Materials and methods}

Defining current disproportions in nutrition maintenance by meat and milk should be started from determining main tendencies in dynamics of key economic indicators of Ukrainian animal husbandry as a part of the general agricultural analysis, performed by Vasylieva et al. (2015). Ministry of Health Care grounded annual rational norms of nutrition per capita in Ukraine, including bread, sugar, oil, potato, vegetables, fruit, meat, milk, and eggs. Ukrainian Ministry of Agricultural Policy and Food applies them to assessing capacities of domestic markets and monitoring level of food security by products and regions (Lupenko and Mesel-Veselyak, 2012). Annual rational diet includes $75 \mathrm{~kg}$ of meat and $330 \mathrm{~kg}$ of milk per capita that are anchor points in indicating saturation of domestic markets and grounding export abilities.

After becoming aware of degradation in Ukrainian animal husbandry its components should be studied more thoroughly. According to Todaro (2014) and Lee (2014), modern mathematical apparatus offers a broad spectrum of procedures for setting and assessing data entropies, especially widespread in incomes management or estimations of economic development. For quick responding to rapid changes in economic environment and better adjusting to regional features of agricultural activity it is expedient to conduct and revise assessments of inequalities in meat and milk production and consumption at the latest 
annual official statistical data by 24 Ukrainian regions (State Statistics Service of Ukraine, 2017). Set of agricultural and economic indicators to Ukrainian regions are aggregated in Annex. In particular,

- \#1 is a share of population by Ukrainian regions, $\%$;

- \#2 denotes a number of cattle, thousands heads;

- $\quad$ \#3 is a number of pigs, thousands heads;

- \#4 denotes a daily average live weight gain of cattle, $g$;

- \#5 is a daily average live weight gain of pigs, $\mathrm{g}$;

- \#6 denotes an annual average milk yield per cow, kg;

- \#7 is a share of arable regional lands under fodder crops, $\%$;

- \#8 denotes an annual meat production per capita, kg;

- \#9 is an annual meat consumption per capita, $\mathrm{kg}$;

- \#10 denotes an annual milk production per capita, $\mathrm{kg}$;

- \#11 is an annual milk consumption per capita, kg.

Aligning production and consumption by regions would provide local food security, reduce expenses in transport and storage logistics, encourage regional farmers in running effective meat and milk agribusiness under the concept of rural development (Velychko, 2013).

In this research the chosen indicators of inequality, applied to Agricultural Economics, were Lorenz curve, Hoover and Theil indices, Gini coefficient, and also 20:20 Ratio. The reasons for such a choice of the listed set of tools were the next ones. Firstly, the Lorenz curve method allows visual scanning and supports regular qualitative monitoring of tendencies in misbalanced meat and milk production and consumption. Secondly, in order to obtain quantitative descriptions of the existing disproportions, it is expedient to apply Hoover index $(H)$. It estimates the highest level of inequality, while Theil index $(T)$ assesses its general average distribution. Finally, Gini coefficient $(G)$ gives a total measure of the inequality, while 20:20 Ratio $(R)$ permits comparing its maximum and minimum limits.

After the identification of the core of misbalances in Ukrainian food security by meat and milk one should suggest some ways of solving the problem in question. Contemporary fundamental approaches to strategic improvements in Agribusiness and Farm Management were accumulated by Olson (2010), Beierlein et al. (2013), Popescu and JeanVasile (2015), Kay et al. (2015). Extensions of their results to the problem in question made possible to specify relevant reserves of strengthening meat and milk components of Ukrainian food security, connected with production productivity, wholesale and retail prices, and solvency of consumers. Data for such calculations are available for free at official site of State Statistics Service of Ukraine.

Firstly, let us have a production segment with a share of $s_{I}$ and animal productivity $p_{I}$. Then in case of increasing productivity in all segments up to

$p_{\max }=\max _{l} p_{l}$,

the total additional share of production $\Delta s$ can be calculated with the formula

$\Delta s=\sum_{l} s_{l}\left(p_{\max } / p_{l}-1\right)$.

Secondly, let us denote $Z-$ a current production profitability, $P^{w}-$ a wholesale price of the considered product. Then the necessary increase in the wholesale price $\left(\Delta P^{w}\right)$, which facilitates production profitability at the desired level of $Z^{\text {opt }}$, can be found with the formula

$\Delta P^{w}=P^{w}\left(Z^{\text {opt }}-Z\right) /(Z+100)$.

Thirdly, let us designate $W^{\text {min }}$ - a minimum month's wage in the country, $P^{r}-$ a retail price of the considered product. Than to compare solvency of population by meat and milk $(S)$ in different countries it is expedient to apply the formula

$S=W^{\min } / P^{r}$.

Finally, let $f$ be a coefficient that transforms a wholesale price into a retail one. Then a grounded value of $f$ enables us to estimate a decrease $\Delta P^{r}$ in the retail price of the considered product with the equality

$\Delta P^{r}=P^{r}-f\left(\Delta P^{w}+P^{w}\right)$.

Joint innovative improvements of meat and milk production and consumption would accelerate their implementations, reduce costs, and increase effectiveness. So, to unite regions with the similar tendencies in meat and milk production and consumption it is expedient to divide them between several interregional clusters. The offered mathematical model to such 
development was stated as follows. Namely, let us denote the given components of a statistical sample to the region $i$ with

$X_{1 i}$ - an annual meat production per capita;

$X_{2 i}$ - an annual meat consumption per capita;

$X_{3 i}$ - an annual milk production per capita;

$X_{4 i}$ - an annual milk consumption per capita.

Let $Y_{1 j}, Y_{2 j}, Y_{3 j}, Y_{4 j}$ be the corresponding unknown in advance average values of the listed indicators to the cluster $j$. Then the proposed optimization model of defining interregional meat and milk clusters searches for such their centers $Y_{1 j}, Y_{2 j}$, $Y_{3 j}, Y_{4 j}$ that maintain minimum of the objective function

$\sum_{i} \min _{j} \sum_{k=1, \ldots, 4}\left(X_{k i}-Y_{k j}\right)^{2} \rightarrow \min$.

All the listed theoretical developments and conclusions on providing food security in the meat and milk clusters were verified and illustrated by the calculations at the annual statistical data to Ukrainian agriculture, obtained from the official electronic resource (State Statistics Service of Ukraine, 2017).

\section{Results and discussion}

\section{Analysis of misbalances}

Official statistical data (State Statistics Service of Ukraine, 2017) disclose an immense reduction of the structural share of Ukrainian animal production from $48.5 \%$ down to $29.7 \%$ that is 2.4 times less than the structural share of Ukrainian crop production. This striking interbranch imbalance was caused by the decrease in meat production by $53.3 \%$ from 4357.8 thousands tons down to 2322.6 thousands tons in 1990-2016. Essential reductions of government support, disproportions between expenses, wholesale and retail prices, lack of experience in market competition affected Ukrainian farmers since 1991. Significant inflation decreased population's solvency and, consequently, capacities of meat consumption, as even importers could not propose affordable prices. However, it should be noted that the worst value of 1517.4 thousands tons was in 2001, and since then meat production has been demonstrating slow, but consistent recovery. A state of milk production is characterized by negative stable shrinking by $43.3 \%$ from 24503.8 thousands tons down to 10615.4 thousands tons at the same period. Indicators of annual meat $(84 \mathrm{~kg})$ and milk $(472.3 \mathrm{~kg})$ production per capita in 1990 even exceeded human rational nutrition norms, respectively $75 \mathrm{~kg}$ and $330 \mathrm{~kg}$. The corresponding milk consumption $(373.2 \mathrm{~kg})$ was sufficient. Yet the volume of meat consumption, only $68.2 \mathrm{~kg}$, was by $9 \%$ lower than the recommended nutrition norm. At present the indicators of meat annual production and consumption per capita are equal to $54.2 \mathrm{~kg}$ and $50.9 \mathrm{~kg}$, which, on the one hand, remain worse by $35.5 \%$ and $25.4 \%$ than those ones in 1990 , but, on the other hand, are essentially higher than a critical production of $31.2 \mathrm{~kg}$ and an extremely insufficient consumption of $31.1 \mathrm{~kg}$ in 2001 . Similarly, the current indicators of milk annual production and consumption per capita are equal to $247.8 \mathrm{~kg}$ and $209.9 \mathrm{~kg}$, which are almost 2 times worse than those ones in 1990. Furthermore, they are only slightly higher than $242.5 \mathrm{~kg}$ of milk, produced per capita in 2011, and $199.1 \mathrm{~kg}$ of milk, consumed per capita in 2000 .

The accomplished calculations of inequality in production and consumption of meat and milk in Ukraine resulted in the following. Figure 1 contains Lorenz curve on an unequal interregional distribution of meat production in Ukraine. Accompanying indicators of the disproportion are

$$
\begin{aligned}
G_{p \text { meat }} & =0.3677, T_{p \text { meat }}=0.2584, \\
R_{p \text { meat }} & =6.88, H_{p \text { meat }}=0.2566 .
\end{aligned}
$$

They mean that the total misbalance of meat supply from domestic producers is $36.77 \%$. Though the inequality entropy has an average level of $25.84 \%$, but the gap between top $20 \%$ and bottom $20 \%$ of meat producers reaches 6.88 times. To align their concentration meat production needs replacement by $25.66 \%$.

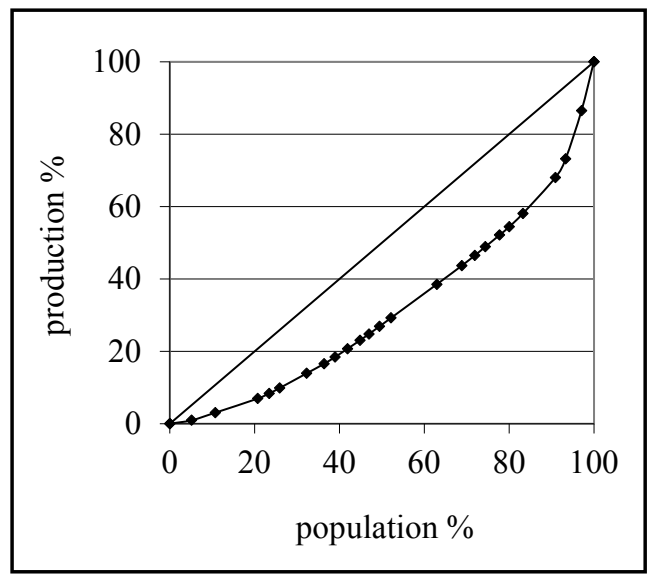

Note: population $=24$ Ukrainian regions

Source: own calculation based on State Statistics Service of Ukraine (2017)

Figure 1: Lorenz curve on inequality of meat production in Ukraine. 
Figure 2 shows Lorenz curve on an inequality of meat consumption in Ukraine. Lorenz curves at Figure 1 and Figure 2 confirm relatively uniform meat consumption in comparison with its production in Ukrainian agriculture. The calculated indicators of inequality in meat consumption are

$$
\begin{aligned}
G_{c \text { meat }} & =0.0703, T_{c_{\text {meat }}}=0.0084, \\
R_{\text {c meal }} & =1.44, H_{c_{\text {meal }}}=0.0488 .
\end{aligned}
$$

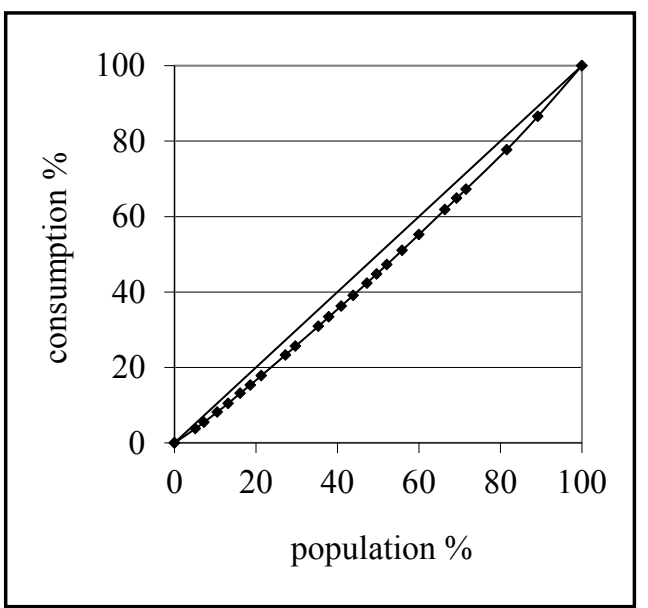

Note: population $=24$ Ukrainian regions

Source: own calculation based on State Statistics Service of Ukraine (2017)

Figure 2: Lorenz curve on inequality of meat consumption in Ukraine.

Their economic interpretation explains that the total disproportion of meat nutrition in Ukraine is $7.03 \%$, at the same time its inequality entropy $(0.84 \%)$ is also low. The difference between top $20 \%$ and bottom $20 \%$ in meat consumption reaches $44 \%$. It would be eliminated after redistribution of meat consumption by $4.88 \%$.

Lorenz curve at Figure 3 visualizes an unequal interregional distribution of milk production in Ukraine. It has a more misbalanced state with respect to domestic meat production, illustrated by Figure 1. Accompanying indicators of the disproportion in milk production are

$$
\begin{aligned}
& G_{p \text { milk }}=0.3593, T_{p \text { milk }}=0.2250, \\
& R_{p \text { milk }}=7.79, H_{p \text { milk }}=0.2806 .
\end{aligned}
$$

They reveal that the total misbalance of milk supply from Ukrainian producers is $35.93 \%$. Though the inequality entropy has an average level of $22.50 \%$, but the gap between top $20 \%$ and bottom $20 \%$ of milk producers reaches striking 7.79 times. To align their concentration milk production needs replacement by $28.06 \%$.

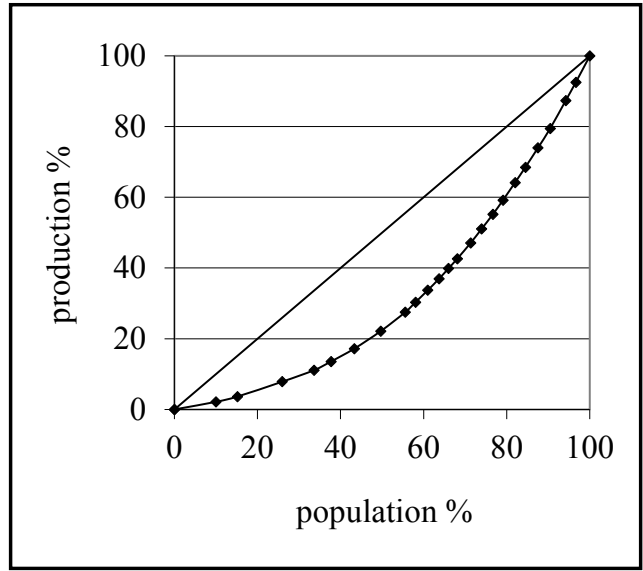

Note: population $=24$ Ukrainian regions

Source: own calculation based on State Statistics Service of Ukraine (2017)

Figure 3: Lorenz curve on inequality of milk production in Ukraine.

Lorenz curve at Figure 4 describes an inequality of milk consumption in Ukraine. Like in the pair of meat production-consumption, Lorenz curves at Figure 3 and Figure 4 confirm relatively uniform milk consumption in comparison with its production in Ukrainian agriculture. Measures of inequalities in milk and meat consumption are almost similar. The calculated indicators of an inequality in milk consumption are

$$
\begin{aligned}
& G_{\text {c milk }}=0.0690, T_{\text {c milk }}=0.0076, \\
& R_{c \text { milk }}=1.43, H_{c \text { milk }}=0.0518 .
\end{aligned}
$$

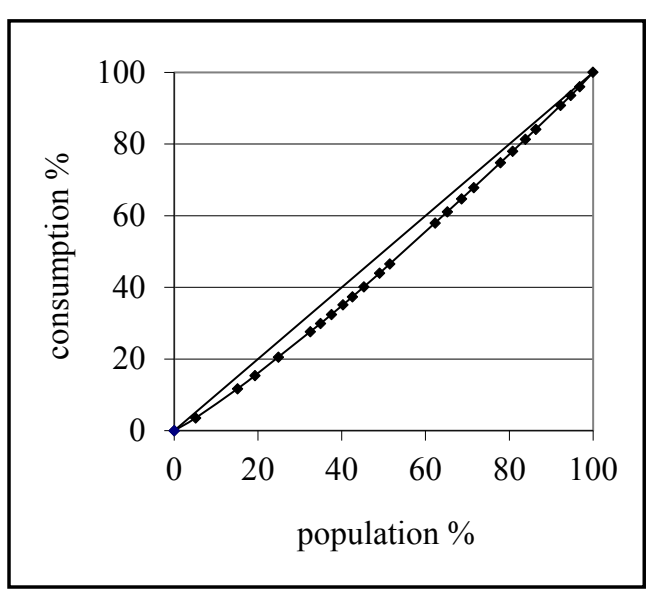

Note: population $=24$ Ukrainian regions

Source: own calculation based on State Statistics Service of Ukraine (2017)

Figure 4: Lorenz curve on inequality of milk consumption in Ukraine.

Their economic interpretation discloses that the total disproportion of milk nutrition in Ukraine is $6.90 \%$, at the same time its inequality entropy 
$(0.76 \%)$ is also low. The difference between top $20 \%$ and bottom $20 \%$ in milk consumption reaches $43 \%$. It would be eliminated after redistribution of milk consumption by $5.18 \%$.

\section{Options of increasing production} and consumption

Positive and long-term experiences of the countries, leading in the effective animal husbandry, enable us to be optimistic about prospects of nutrition maintenance by meat and milk in Ukraine. Official statistical data (FAO, 2017) convince that Ukrainian meat producers should pattern the farmers from leading countries, where annual meat production per capita achieves $82 \mathrm{~kg}$ (in Hungary), $86 \mathrm{~kg}$ (in France), $99 \mathrm{~kg}$ (in Germany), $100 \mathrm{~kg}$ (in Poland), $106 \mathrm{~kg}$ (in Austria), $116 \mathrm{~kg}$ (in Spain), $123 \mathrm{~kg}$ (in Canada), $130 \mathrm{~kg}$ (in Brazil), $133 \mathrm{~kg}$ (in the USA), $159 \mathrm{~kg}$ (in the Netherlands), $337 \mathrm{~kg}$ (in Denmark). By the way, the above mentioned countries not only provide their domestic food security, but also facilitate it in the global scale. In particular, the USA took the 1st, the Netherlands $-3^{\text {rd }}$, Germany $-5^{\text {th }}$, Canada $-6^{\text {th }}$, Poland $-7^{\text {th }}$, and France $-9^{\text {th }}$ place among the World Top Fresh Beef Exporting Countries. Brazil was at the $3^{\text {rd }}$, the USA $-4^{\text {th }}$, Canada $-9^{\text {th }}$, and Poland $-10^{\text {th }}$ position in the World Top Frozen Beef Exporters List. The USA took $1 \mathrm{st}$, Germany $-2^{\text {nd }}$, Spain $-3^{\text {rd }}$, Denmark $-4^{\text {th }}$, Canada $-5^{\text {th }}$, the Netherlands $-6^{\text {th }}$, Brazil $-8^{\text {th }}$, France $-9^{\text {th }}$, Poland $-10^{\text {th }}$, Austria $-14^{\text {th }}$, and Hungary $-15^{\text {th }}$ place among the World Top Pork Exporting Countries. The Netherlands were at the $1^{\text {st }}$, the USA $-2^{\text {nd }}$, Poland $-3^{\text {rd }}$, Germany $-5^{\text {th }}$, France $-7^{\text {th }}$, Hungary $-10^{\text {th }}$, and Austria $-12^{\text {th }}$ position in the World Top Fresh Chicken Exporters List. Brazil took the $1^{\text {st }}$, the USA $-2^{\text {nd }}$, the Netherlands $-3^{\text {rd }}$, Poland $-5^{\text {th }}$, and France $-6^{\text {th }}$ place among the World Top Frozen Chicken Exporting Countries (World's Top Exports, 2015).

Similarly, Ukrainian milk production should be rearranged like those ones in the leading countries, where annual milk production per capita is $333 \mathrm{~kg}$ (in Poland), $376 \mathrm{~kg}$ (in Germany), $382 \mathrm{~kg}$ (in France), $404 \mathrm{~kg}$ (in Austria), $742 \mathrm{~kg}$ (in the Netherlands), and $908 \mathrm{~kg}$ (in Denmark) (FAO, 2017). As before, the above named countries have sufficient milk nutrition maintenance and make their immense contribution into the global food security system. Indeed, Germany was at the $1^{\text {st }}$, France $-2^{\text {nd }}$, the Netherlands $-4^{\text {th }}$, Austria $-5^{\text {th }}$, Poland $-8^{\text {th }}$, and Denmark $12^{\text {th }}$ place in the World Top Milk Exporters List (World's Top Exports, 2015).
The dominant raw for dairy products in Ukraine is cow milk. The main kinds of meat in Ukrainian agriculture are poultry meat, pork and beef with the structural shares $49.2 \%, 32.7 \%, 16.5 \%$ in 2016 (State Statistics Service of Ukraine, 2017). It should be underlined that production of poultry meat has been increasing its share since 1990 , starting from $16.3 \%$. At the same time, pork and beef production have been losing their shares since 1990, starting from $36.2 \%$ and $45.5 \%$. Nutrition norms suppose almost equal proportions of beef, pork and poultry meat. These arguments forced us to focus this research on strengthening livestock breeding. Furthermore, volumes of beef and pork production in Ukraine diminished critically 2.1 and 5.2 times in 1990-2016 (State Statistics Service of Ukraine, 2017).

Positive world agricultural experience grounds that the key approach to achieving prosperous and competitive animal husbandry lies in raising animals' productivities. State Statistics Service of Ukraine provides available data on annual average milk yield per cow from 1000 to $6000 \mathrm{~kg}$ with a step of $1000 \mathrm{~kg}$. Statistical analysis of dependency of total milk production on annual average milk yield per cow in Ukrainian agriculture demonstrates their convincing parallel increase (see Figure 5). It is highlighted by the non-linear regression

$$
y=0.2759 e^{0.0008 x}
$$

with the coefficient of determination $R^{2}=0.9307$. Farmers with an annual average milk yield per cow over $6000 \mathrm{~kg}$ provide $55.1 \%$ of total milk production. Calculations with the formulae (1) and (2) gave $p_{\max }=6000$ and $\Delta s=0.293$. In other words, in case of the general growth of cows' productivities up to the accessible level of $6000 \mathrm{~kg}$, it would raise total Ukrainian milk production by $29.3 \%$ or up to $320.3 \mathrm{~kg}$ of annual milk production per capita. Besides, the latter value approximately coincides with those ones in Poland, Sweden and the USA. So, this gives us confidence that the calculated reserves could partly solve a problem of nutrition maintenance in Ukrainian milk husbandry. 


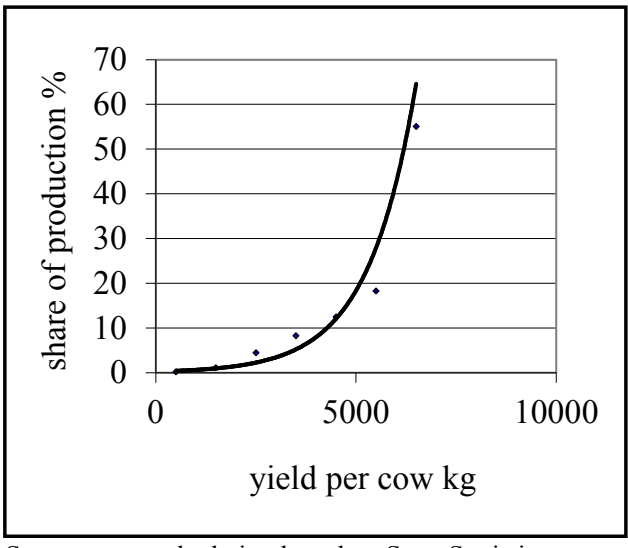

Source: own calculation based on State Statistics Service of Ukraine (2017)

Figure 5: Dependency of milk production on yield per cow in Ukraine.

State Statistics Service of Ukraine provides available data on daily average live weight gain of pigs from 50 to $500 \mathrm{~g}$ with a step of $50 \mathrm{~g}$. As before, statistical analysis discloses that total pork production and daily average live weight gain of pigs in Ukrainian agriculture are characterized by parallel growing (see Figure 6). It is highlighted by the non-linear regression

$$
y=10^{-8} x^{4}-10^{-5} x^{3}+0.0036 x^{2}-0.359 x+9.2914
$$

with the coefficient of determination $R^{2}=0.9557$. Farmers with daily gain per head of pigs over $500 \mathrm{~g}$ provide $64.7 \%$ of total pork production. Calculations with the formulae (1) and (2) gave $p_{\max }=500$ and $\Delta s=0.279$. In other words, in case of the general increase of pigs' productivities up to the available level of $500 \mathrm{~g}$, it would bring additional $27.9 \%$ of total Ukrainian pork production or raise annual pork production per capita from the current $17.7 \mathrm{~kg}$ to $22.6 \mathrm{~kg}$.

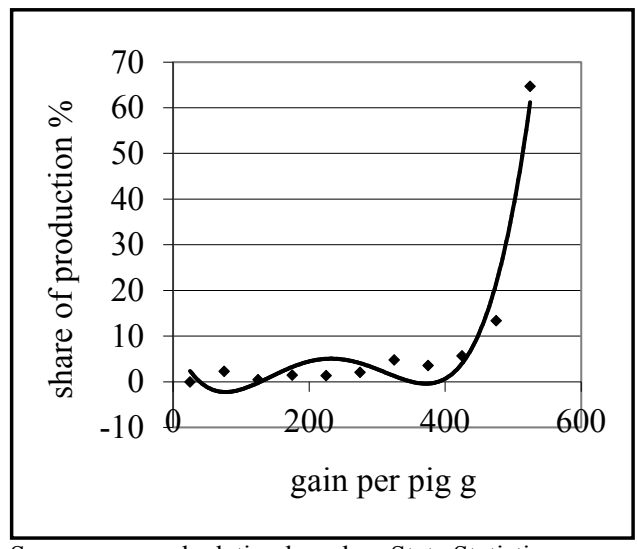

Source: own calculation based on State Statistics Service of Ukraine (2017)

Figure 6: Dependency of pork production on gain per pig in Ukraine.
State Statistics Service of Ukraine provides available data on daily average live weight gain of cattle from 100 to $900 \mathrm{~g}$ with a step of $100 \mathrm{~g}$. Statistical analysis of dependency of total beef production on daily average live weight gain of cattle visualizes that the core of production corresponds to an average cattle's productivity (see Figure 7). It is highlighted by the non-linear regression

$y=4 \cdot 10^{-10} x^{4}-10^{-6} x^{3}+0.0007 x^{2}-0.1367 x+6.2773$

with the coefficient of determination $R^{2}=0.937$. The ways of improving such a situation lie in changing breeds of cattle into modern highproductive ones and implementing innovative intensive technologies of beef production. Calculations with the formulae (1) and (2) gave $p_{\max }=900$ and $\Delta s=0.78$. In other words, in case of the general growth of cattle's productivity to the accessible level of $900 \mathrm{~g}$, it would raise total Ukrainian beef production by $78 \%$ or up to $16 \mathrm{~kg}$ instead of the current $9 \mathrm{~kg}$ of annual beef production per capita. Thus, total annual meat production per capita would reach $66.1 \mathrm{~kg}$ that approximately coincides with those ones in Italy and the United Kingdom. So the calculated reserves assure us of real opportunities of enhancing nutrition maintenance in Ukrainian meat husbandry.

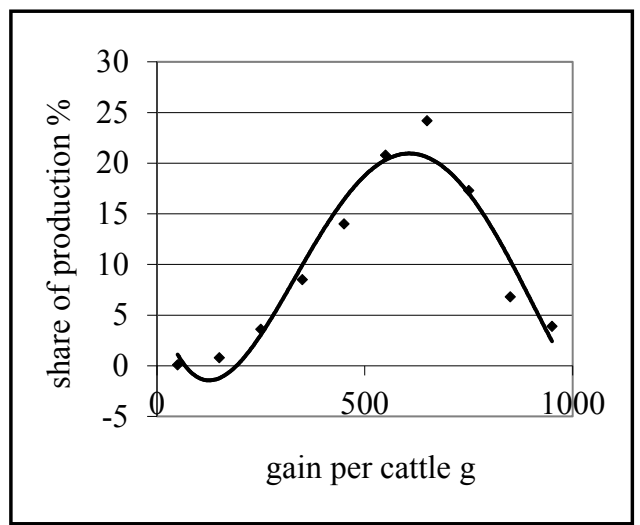

Source: own calculation based on State Statistics Service of Ukraine (2017)

Figure 7: Dependency of beef production on gain per cattle in Ukraine.

Sustainable development immensely depends on permanent monitoring and adjusting of prices, costs and profitability. These concern not only agricultural economics in general (Norton et al., 2014), but also affect meat and milk clusters (Bakucs and Ferto, 2015; Zakova Kroupova, 2016). Indeed, practice reveals that improvements of productivities in domestic livestock breeding have been braking by low unstable incomes and frequently even unprofitable results. First, 
for the past 10 years breeding of pigs was 4 times unprofitable down to $-27.6 \%$ and 6 times profitable up to $12.6 \%$. Second, milk production has been operating with incomes. But their abrupt changes in profitability, ranging between $1.4 \%$ and $18.5 \%$, cannot be associated with expanded reproduction. Third, cattle breeding appeared to be in the worst state, running with losses from $-16.9 \%$ down to $-43.3 \%$. The key reasons of the introduced situations are low wholesale prices for meat and milk in Ukrainian agriculture. They $\left(P^{w}\right)$ were US\$ 813.56 per livestock ton in live weight and US\$ 161.01 per ton of milk, while the retail prices $\left(P^{r}\right)$ per $\mathrm{kg}$ of beef (slaughter coefficient 0.7 ), pork (slaughter coefficient 0.8 ) and milk were US\$ 3.89, US\$ 3.33, US\$ 0.56 in 2016 (State Statistics Service of Ukraine, 2017). Corrections of the described disproportions outline the second reserve in facilitating food security in Ukrainian animal husbandry, while prices in domestic crop production are almost equal to the world level (Vasylieva and Pugach, 2017). The performed calculations with formula (3) showed that increasing wholesale price for cattle in live weight by $50.42 \%$ up to US\$ 1223.77 per ton will provide profitability of beef production at the level of $25 \%$ $\left(Z^{o p t}\right)$. Similarly, raising wholesale prices for pigs in live weight by $33.21 \%$ up to US\$ 1083.79 per ton and for milk by $33.10 \%$ up to US\$ 214.30 per ton will guarantee expanded pork and milk production with $50 \%$ of profitability $\left(Z^{o p t}\right)$.

Recent analysis of retail prices and solvency of population (Bakucs and Ferto, 2015; Benda Prokeinova and Hanova, 2016) permitted us to ground some reserves on improving consumption of meat and milk as components of nutrition maintenance in Ukrainian food security. Certainly, the retail prices for beef, pork and milk in Ukraine are less by $37 \%, 28 \%$ and $24 \%$ than those ones in Eastern Europe (concerning Hungary, Lithuania and Poland), 3.1, 2.6 times and by $70 \%$ less than in Western Europe (regarding Austria, France and the Netherlands), 2.2, 2.2 and 2.3 times less than in North America (with respect to Canada and the USA) (FAO, 2017). But simultaneously, Ukrainian population has poor solvency that is identified by the value of the official minimum wage $W^{\text {min }}$ (see Table 1).

Calculations with formula (4) justified this conclusion. Indeed, the minimum month's wage in Ukraine allows people to buy $30 \mathrm{~kg}$ of beef, $35 \mathrm{~kg}$ of pork and $212 \mathrm{~kg}$ of milk. At the same time, $98 \mathrm{~kg}, 127 \mathrm{~kg}$ and $736 \mathrm{~kg}$ of these products are available per average minimum month's wage in the listed countries of Eastern Europe, $132 \mathrm{~kg}$, $182 \mathrm{~kg}$ and $1650 \mathrm{~kg}$ - in Western Europe, $161 \mathrm{~kg}$, $196 \mathrm{~kg}$ and $1137 \mathrm{~kg}$ - in North America. So, the first reserve of improving consumption of meat and milk, as a component of nutrition maintenance in Ukrainian food security, assumes the increase in the minimum wage. However, implementation of this issue implies further persistent and unavoidable state reforms, focused on strong control and transparency of budget revenues and expenditures.

\begin{tabular}{lc}
\hline Country & $W^{\text {min }}$, US\$ per month \\
\hline Ukraine & 118.00 \\
\hline Eastern Europe & \\
\hline Hungary & 560.00 \\
Lithuania & 423.00 \\
Poland & 475.00 \\
\hline Western Europe & 1320.00 \\
\hline Austria & 1657.17 \\
France & 1722.75 \\
The Netherlands & 1524.50 \\
\hline North America & 1256.67 \\
\hline Canada & \\
The USA & \\
\hline Source: based on Minimum wage rates by country (2017) \\
\end{tabular}

The second reserve in enhancing solvency of Ukrainian population is based on the above calculated changes in prices. Firstly, it is expedient to set $50 \%$ structural share of agricultural producers in the retail prices of meat and milk. Secondly, it is necessary to cut disproportionately high structural share down to $50 \%$ of the retail prices for processing and trade services, partly compensating their losses by some tax privileges, i.e. $f=2$. Finally, according to the formula (5) even under the above calculated increase in meat and milk wholesale prices $\left(\Delta P^{w}\right)$, the retail prices per $\mathrm{kg}$ of beef, pork and milk could diminish by $10.09 \%$, $18.72 \%$ and $22.85 \%$ down to US\$ 3.50 , US\$ 2.71 and US\$ 0.43 . As a result, it would generate growing in demands, in turn, stimulating increases in supplies for meat and milk and, eventually, facilitating the desired improvements of food security in Ukrainian animal husbandry.

Priorities of applying the described options on providing food security in meat and milk clusters need strict substantiations under the current conditions of poor financing. Cluster approach confirmed its effectiveness in Ukrainian crop production and animal husbandry 
(Vasylieva, 2016; Vasylieva and Pugach, 2017). Calculations, accomplished with the model (6) by means of the instrument NXL Clusterizer, made possible to divide 24 Ukrainian regions into 3 interregional clusters. Their profiles, including average characteristics $Y_{l i}, Y_{2 j}, Y_{3 j}, Y_{4 j}$ and the corresponding average weighted deviations around average Ukrainian annual meat and milk production and consumption $\Delta Y_{1 j}, \Delta Y_{2 j}, \Delta Y_{3 j}, \Delta Y_{4 j}$ were collected in Table 2.

The performed analysis of Table 2 showed that, firstly, cluster 1 aggregated 8 regions, where consumption of meat and milk essentially dominated over their domestic production. Therefore, the priority options on providing food security and reducing such disproportions should be connected with the clarified increases in productivity and wholesale prices.

Secondly, cluster 2 united 8 regions with the most balanced Ukrainian meat and milk production and consumption. A comparison of meat and milk segments confirmed recommendations to focus on improving meat production and consumption that demonstrated worse results than those ones for milk.

\begin{tabular}{|c|c|c|c|}
\hline \multirow{2}{*}{ Indicators } & \multicolumn{3}{|c|}{ Clusters } \\
\hline & 1 & 2 & 3 \\
\hline$Y_{1 \mathrm{j}}, \mathrm{kg}$ & 35.5 & 45.5 & 98.8 \\
\hline$Y_{2 j}, \mathrm{~kg}$ & 52.0 & 46.0 & 49.4 \\
\hline$Y_{3 j}, \mathrm{~kg}$ & 138.8 & 317.4 & 471.6 \\
\hline$Y_{4 \mathrm{j}}, \mathrm{kg}$ & 192.3 & 224.1 & 228.0 \\
\hline$\Delta Y_{l j}, \%$ & -40.8 & -24.0 & 64.8 \\
\hline$\Delta Y_{2 j}, \%$ & 5.9 & -6.4 & 0.6 \\
\hline$\Delta Y_{3 j}, \%$ & -55.1 & 2.6 & 52.5 \\
\hline$\Delta Y_{4 \mathrm{i}}, \%$ & -10.5 & 4.3 & 6.1 \\
\hline
\end{tabular}

Source: own calculation based on State Statistics Service of Ukraine (2017)

Table 2: Profiles of Ukrainian interregional meat and milk clusters.

Finally, cluster 3 comprised 8 regions, where production of meat and milk dominated over their domestic consumption. It implies that the priority options on providing food security and reducing such disproportions should be linked with the possible increase in customers' solvency and grounded shrink of retail prices.

\section{Conclusion}

Economic results of the accomplished research are focused on saturating and aligning domestic meat and milk markets. The issue of providing food security by means of balancing production and consumption in the agricultural clusters has double economic and social importance in the global scale and for every country. Nutrition maintenance in the clusters of animal products is a fundamental task in the frame of supporting food security in Ukraine. The most ruined states of production and consumption have been set for beef, pork and cow milk, which capacities diminished 5.2, 2.1 and 2.3 times in 1990-2016.

In comparison with general and conceptional studies on Food Security of Headey and Ecker (2013), Godfray and Garnett (2014), Kavallari et al. (2014), Grafton et al. (2015), this research established quantitative evaluations and options, confirmed by figures, as for facilitating specific branch of meat and milk production. While Bakucs and Ferto, (2015), Zakova Kroupova (2016), Benda Prokeinova and Hanova (2016) explored meat and milk markets in Hungary, Slovakia, and the Czech Republic, the identified in the article disproportions and found reserves of the further improvements concerned the Ukrainian agriculture.

Lorenz curves together with the inequality indicators have visualized the essential interregional misbalances in meat and milk production that need aligning replacement on average by $26.9 \%$. The same calculations have highlighted more uniform states in consumption of meat and milk, where satisfactions of top $20 \%$ and bottom $20 \%$ of consumers vary on average by $43.5 \%$.

The recovery of Ukrainian meat and milk production should be focused on the capacities in 1990, when they were enough not only for providing the domestic food security, but also for participating in support of food security in the global scale. It has been grounded that the appropriate reserves to achieve this goal would be connected with

- increasing animal productivity, which could bring additional $78 \%, 27.9 \%$ and $29.3 \%$ of beef, pork and milk;

- raising their wholesale prices that might provide stable profitable expanded reproduction.

The perspective reserves of improving meat and milk consumption have been associated with

- the decrease in retail prices for beef, pork and milk by $50.4 \%, 33.2 \%$ and $33.1 \%$;

- the growth of the minimum wage for strengthening solvency of Ukrainian population.

The proposed model of defining interregional clusters has made possible to focus on priority 
options of providing food security and balancing meat and milk production and consumption in conditions of restricted financing. Cluster model enables Ukrainian farmers to share experience and knowledge in solving similar economic problems, as well as gain advantages in supporting regional food security in meat and milk segments.

In general, the accomplished investigation has confirmed the effectiveness of applying the contemporary mathematical apparatus to assessing misbalances and finding reserves of nutrition maintenance in Ukrainian food security. It inspires us to extend the obtained results at the other products clusters, applying wider spectrum of mathematical methods in the further scientific research.

Corresponding author:

Prof. Natalia Vasylieva

Department of Informative Systems and Technologies, Faculty of Accounting and Finances,

Dnipro State Agrarian and Economic University, 25 Serhiya Yefremova Str., Dnipro, 49600, Ukraine

Phone: +38-098-033-4900,E-mail:VasylievaN@i.ua

\section{References}

[1] Bakucs, Z. and Ferto, I. (2015) "Empirical tests of sale theories: Hungarian milk prices“, Agricultural Economics, Vol. 61, No. 11, pp. 511-521. ISSN 0139-570X. DOI 10.17221/168/2014-AGRICECON.

[2] Beierlein, J. G., Schneeberger, K. C. and Osburn, D. D. (2013) "Principles of Agribusiness Management", Long Grove: Waveland Press, Inc., p. 378. ISBN 978-1478605669.

[3] Bessler, D. A., Doefman, J. H., Holt, M. T. and LaFrance, J. T. (2010) "Econometric Developments in Agricultural and Resource Economics: The First 100 Years", American Journal of Agricultural Economics, Vol. 92, No. 2, pp. 571-589. ISSN 0002-9092. DOI 10.1093/ajae/aaq010.

[4] Benda Prokeinova, R. and Hanova, M. (2016) "Modelling consumer's behaviour of the meat consumption in Slovakia“, Agricultural Economics, Vol. 62, No. 5, pp. 235-245. ISSN 0139-570X. DOI 10.17221/33/2015-AGRICECON.

[5] FAO (2017) "Food and Agriculture Organization of the United Nations“, Statistics, Jan. 2017. [Online]. Available: http://www.fao.org/faostat/en/\#data [Accessed: 5 Apr. 2017].

[6] Godfray, H. C. J. and Garnett, T. (2014) "Food security and sustainable intensification", Philosophical Transaction of the Royal Society B, 369: 20120273. Jan. 2017. [Online]. Available: http://dx.doi.org/10.1098/rstb.2012.0273 [Accessed: 5 Apr. 2017]. ISSN 0962-8436. DOI 10.1098/ rstb.2012.0273.

[7] Grafton, R. Q., Daugbjerg, C. and Qureshi, M. E. (2015) "Towards food security by 2050“, Food Security, Vol. 7, No. 2, pp. 179-183. ISSN 1876-4517. DOI 10.1007/s12571-015-0445-x.

[8] Hansen, H. O. (2013) "Food Economics: Industry and Markets (Series: Textbooks in Environmental and Agricultural Economics)“, London: Routledge, p. 448. ISBN 978-0415604611.

[9] Headey, D. and Ecker, O. (2013) "Rethinking the measurement of food security: from first principles to best practice“, Food Security, Vol. 5, No. 3, pp. 327-343. ISSN 1876-4517. DOI 10.1007/s12571-013-0253-0.

[10] Kavallari, A., Fellmann, T. and Gay, S. H. (2014) "Shocks in economic growth = shocking effects for food security?", Food Security, Vol. 6, No. 4, pp. 567-583. ISSN 1876-4517. DOI 10.1007/s12571-014-0368-y.

[11] Kay, R., Edwards, W. and Duffy, P. (2015) "Farm Management", New York: McGraw-Hill Education, p. 480. ISBN 978-0073545875.

[12] Lee, H. (2014) "Foundations of Applied Statistical Methods", New York: Springer, p. 161. ISBN 978-3319024011. DOI 10.1007/978-3-319-02402-8.

[13] Lupenko, Yu. O. and Mesel-Veselyak, V. Ya. (2012) “Strategic Directions of Agricultural Development in Ukraine till 2020”, Kyiv: National Scientific Center “Institute of Agricultural Economics”, p. 218. Aug. 2017. [Online]. Available: http://agroua.net/docs/strateg.pdf [Accessed: 16 Aug. 2017]. 
[14] Minimum Wage Rates by Country. (2017) Aug. 2017. [Online]. Available: http://www.wageindicator. org/main/salary/minimum-wage [Accessed: 16 Aug. 2017].

[15] Mitchell, N. H. (2011) "Mathematical Applications in Agriculture“, Boston: Cengage Learning, p. 304. ISBN 978-1111310660.

[16] Norton, G. W., Alwang, J. and Masters, W. A. (2014) "Economics of Agricultural Development: World Food Systems and Resource Use“, New York: Routledge, p. 464. ISBN 978-0415658232.

[17] Olson, K. D. (2010) "Economics of Farm Management in a Global Setting", Hoboken: Wiley, p. 560. ISBN 978-0470592434.

[18] Phillips, P. W. B., Karwandy, J., Webb, G. and Ryan, C. D. (2012) "Innovation in Agri-food Clusters: Theory and Case Studies", Croydon: CABI, p. 240. ISBN 9781780640419. DOI 10.1079/9781780640419.0000.

[19] Popescu, G. and Jean-Vasile, A. (2015) "Agricultural Management Strategies in a Changing Economy“, Hershey: IGI Global, p. 439. ISBN 978-1466675216. DOI 10.4018/978-1-4666-7521-6.

[20] Porter, M. E. (2000) "Location, Competition, and Economic Development: Local Clusters in a Global Economy“, Economic Development Quarterly, Vol. 14, No. 1, pp. 15-34. ISSN 08912424. DOI 10.1177/089124240001400105.

[21] State Statistics Service of Ukraine (2017) “Agriculture in Ukraine“. Statistics, Apr. 2017. [Online]. Available: http://www.ukrstat.gov.ua/ [Accessed: 5 Apr. 2017].

[22] Thornley, J. H. M. and France, J. (2007) "Mathematical Models in Agriculture: Quantitative Methods for the Plant, Animal and Ecological Sciences“, Trowbridge: CABI, p. 906. ISBN 978-0851990101.

[23] Todaro, M. P. (2014) "Economic Development", Philadelphia: Trans-Atlantic Publications, p. 860. ISBN 978-1292002972.

[24] Vasylieva, N. K. (2015) "Economic and mathematical models of regional meat \& milk cluster development“, Actual Problems of Economics, Vol. 165, No. 3, pp. 429-435. ISSN 1993-6788.

[25] Vasylieva, N. K., Vinichenko, I. I. and Katan, L. I. (2015) "Economic and mathematical evaluation of Ukrainian agrarian market by branches", Economic Annals-XXI, Vol. 154, No. 9-10, pp. 41-44. ISSN 1728-6220.

[26] Vasylieva, N. (2016) "Cluster models of households' agrarian production development", Economic Annals-XXI, Vol. 158, No. 3-4 (2), pp. 13-16. ISSN 1728-6220. DOI 10.21003/ea.V158-03.

[27] Vasylieva, N. K. and Pugach, A. N. (2017) "Economic assessment of technical maintenance in grain production of Ukrainian agriculture", Bulgarian Journal of Agricultural Science, Vol. 23, No. 2, pp. 198-203. ISSN 1310-0351.

[28] Velychko, O. P. (2013) "Methodology for estimation of enterprise logistics development", Actual Problems of Economics, Vol. 146, No. 8, pp. 45-54. ISSN 1993-6788.

[29] World's Top Exports. (2015) "World's Top Exported Fresh Food Products". Statistics, Apr. 2017. [Online]. Available: http://www.worldstopexports.com/category/products/food/freshfood/ [Accessed: 5 Apr. 2017].

[30] Zakova Kroupova, Z. (2016) "Profitability development of Czech dairy farms", Agricultural Economics, Vol. 62, No. 6, pp. 269-279. ISSN 0139-570X. DOI 10.17221/131/2015-AGRICECON. 


\section{Appendix}

\begin{tabular}{|c|c|c|c|c|c|c|c|c|c|c|c|}
\hline Region & \multicolumn{11}{|c|}{ Indicators } \\
\hline Cherkasy & 3 & 186 & 400 & 576 & 435 & 5724 & 8 & 252 & 53 & 425 & 227 \\
\hline Chernihiv & 2 & 205 & 194 & 565 & 428 & 4735 & 11 & 33 & 46 & 526 & 239 \\
\hline Chernivtsi & 2 & 90 & 148 & 528 & 464 & 4764 & 16 & 45 & 41 & 323 & 244 \\
\hline Ivano-Frankivsk & 3 & 159 & 313 & 517 & 716 & 4354 & 21 & 62 & 42 & 343 & 259 \\
\hline Kharkiv & 6 & 196 & 300 & 517 & 466 & 5483 & 6 & 35 & 53 & 193 & 228 \\
\hline Kherson & 2 & 107 & 166 & 565 & 483 & 4163 & 6 & 46 & 51 & 282 & 196 \\
\hline Khmelnytskiy & 3 & 230 & 340 & 598 & 561 & 4175 & 10 & 50 & 49 & 448 & 233 \\
\hline Luhansk & 5 & 58 & 66 & 416 & 285 & 4197 & 4 & 10 & 38 & 72 & 145 \\
\hline Lviv & 6 & 203 & 349 & 530 & 540 & 4180 & 15 & 47 & 47 & 225 & 236 \\
\hline Mykolayiv & 3 & 135 & 115 & 462 & 315 & 4110 & 3 & 28 & 44 & 296 & 207 \\
\hline Odesa & 6 & 179 & 350 & 396 & 390 & 3502 & 4 & 20 & 48 & 161 & 195 \\
\hline Poltava & 3 & 256 & 409 & 568 & 523 & 6016 & 7 & 53 & 50 & 550 & 224 \\
\hline Rivne & 3 & 146 & 282 & 472 & 469 & 4206 & 18 & 47 & 46 & 376 & 213 \\
\hline Sumy & 3 & 147 & 140 & 503 & 411 & 4940 & 7 & 39 & 49 & 373 & 204 \\
\hline Ternopil & 2 & 154 & 440 & 568 & 503 & 4561 & 8 & 52 & 48 & 431 & 235 \\
\hline Ukraine & 100 & 3750 & 7079 & 536 & 482 & 4644 & 7 & 54 & 51 & 248 & 210 \\
\hline
\end{tabular}

Note:

- \#1 is a share of population by Ukrainian regions, \%;

- \#2 denotes a number of cattle, thousands heads;

- \#3 is a number of pigs, thousands heads;

- \#4 denotes a daily average live weight gain of cattle, g;

- \#5 is a daily average live weight gain of pigs, g;

- \#6 denotes an annual average milk yield per cow, kg;

- \#7 is a share of arable regional lands under fodder crops, \%;

- \#8 denotes an annual meat production per capita, $\mathrm{kg}$;

- \#9 is an annual meat consumption per capita, $\mathrm{kg}$;

- \#10 denotes an annual milk production per capita, kg;

- \#11 is an annual milk consumption per capita, $\mathrm{kg}$.

Source: aggregated from State Statistics Service of Ukraine (2017)

Table: Agricultural and economic indicators by Ukrainian regions in 2016. 